\title{
Learn Physics Using Interactive Demonstration to Reduce The Students' Misconceptions on Mechanical Wave
}

\author{
Mukhayyarotin Niswati Rodliyatul Jauhariyah \\ Physics Education Program Study, Physics Department, Faculty of Mathematics and Natural Sciences, Universitas Negeri \\ Surabaya, Indonesia \\ Zaitul Harizah, Indina Zulfa, Herlina Mulyastuti \\ Physics Education Program, Graduate Program, Universitas Negeri Malang, Indonesia
}

\author{
Woro Setyarsih, and Nadi Suprapto \\ Physics Education Program Study, Physics Department, Faculty of Mathematics and Natural Sciences, Universitas Negeri \\ Surabaya, Indonesia
}

\begin{abstract}
In the learning process, students have conception and misconception, no exeption in mechanical wave learning. The aims of this study to reduce students misconceptions on mechanical wave using interactive demonstration. Interactive demonstration of physics learning applied to students of 16th State Senior High School of Surabaya using one group pretestposttest design of research. The results of pretest and posttest show that students misconception on mechanical wave material can reduce using interactive demonstration learning on moderate category.
\end{abstract}

Keywords - Interactive Demonstration, Student Misconseption, Mechanical Wave

\section{INTRODUCTION}

Misconceptions may take the form of an initial concept, inaccurate notions of concepts, the use of false concepts, the classification of false examples of the application of concepts, and the interpretation of different concepts. Suparno [1] stated that misconceptions exist in all areas of science, such as physics, chemistry, and biology. Misconceptions in physics include sub areas such as mechanics, thermodynamics, optics, sounds, waves, electricity and magnetism, as well as modern physics. There are many ways to identify misconception in physics such as interviews, open-ended test, multiple-choice test, multiple-tier test [2]. CRI (Certainty of Response Index) can be used to distinguish between students who understand concepts, do not understand concepts, and misconceptions [34]. However, through RCI it is not known whether students actually experience misconceptions or guesses. Using threetier diagnostic test, it can be known the student who understand the concepts, do not understand the concepts, experience misconceptions, guesses, and false negative [5-8].

According to Suparno [1], misconceptions occur mostly because of the initial misconceptions that students have and are brought into the classroom. The initial concept has an important role in building an understanding of an object being studied. The learning process will run smoothly if the initial concepts that students have are in accordance with the new knowledge acquired. If the initial concept of students is not in accordance with the new knowledge gained, then there will be misconceptions which will later become obstacles in learning [9].

The material of the wave is one of the physics materials that allows students to experience misconception. Elfani stated that when students were asked about the speed ratio between two waves propagating on the same medium with the first wave frequency of $1000 \mathrm{~Hz}$ and the second wave frequency of $3000 \mathrm{~Hz}$, some students answered 1: 3. Though the wave velocity does not depend on the frequency of the wave but on the nature of the medium. Students are fixated on the equation $\mathrm{v}=\square$.f and assume that $\mathrm{f}$ (frequency) is directly proportional to $\mathrm{v}$ (velocity). Whereas in these conditions, $\mathrm{v}$ is constant. Some of the students were convinced of the answer, so Elfani [10] concluded that students had misconceptions on mechanical wave material.

Based on the case found by Elfani, it was assumed that there were still many high school students who experienced 
misconceptions in mechanical wave material. To prove this assumption, identification of students' misconceptions was carried out on the mechanical wave material by compiling a three-tier diagnostic test instrument. The process of developing test instruments is almost the same as when developing a three-tier diagnostic test instrument in the Gas Kinetic Theory material in our previous paper [6]. Based on a combination of students' answers when working on a three-tier diagnostic test instrument, students can experience misconceptions based on criteria adapted from Kutluay [6]. Misconceptions profiles can be analyzed using methods such as when determining the profile of students' misconceptions on the material of the Gas Kinetic Theory [7]. Based on the diagnosis, there were $40.30 \%$ of students in one class at 16th Senior High School of Surabaya who experienced misconceptions on mechanical wave material. Therefore, efforts are needed to reduce the misconception.

There are many ways to reduce student misconceptions on Physics material. Broadly speaking, the steps used to overcome misconceptions are by finding or uncovering misconceptions, trying to find the cause of the misconception, and then finding appropriate treatment to overcome the misconceptions experienced by students [1]. Students' misconceptions cannot be overcome simply by using the lecture method that the entire process of delivering knowledge is teacher-centered. Not all of the methods carried out by the teacher succeed to reduce misconceptions in students. This is because the teacher does not know for sure the cause of misconceptions experienced by students and sometimes the teacher gives inappropriate treatment to deal it. Teachers tend to repeat material that is considered difficult to understand by students. However, students who experience misconceptions will still not be helped because they do not know for certain the location of the error they experienced. Therefore, students must be actively involved in learning and directed to build their own knowledge through real experience in dealing with real physical phenomena.

Berg [11] argued that the key to knowing the occurrence of misconceptions in students is to interact with students. According to Berg [11], students 'misconceptions can be overcome by (1) adjusting the syllabus sequence by students' thinking, (2) cognitive conflict, (3) analogy, (4) pair interaction, (5) meta-learning, meta-cognition, and (6) demonstration. To tackle misconceptions on students, appropriate learning methods are needed in order to create students' cognitive conflicts.

Interactive demonstration becomes one of the solutions to handle student misconception on the subject of physics. West and Ogden [12] stated that interactive demonstration was developed to help students in better learning to make it easier to understand some of the difficult concepts their face. Learning by way of traditional lectures combined with interactive demonstration learning is more effective than learning using traditional lectures [13]. Similar of this studies that the use of multimedia-assisted interactive demonstration learning models has an effect on student learning outcomes in the chemistry aspects of natural science [14]. Student learning outcomes have increased in each learning series after applying the interactive demonstration learning method [15]. The increase in students' understanding of concepts minimizes the possibility of differences in concepts that students have with scientific concepts so that expected physics learning using interactive demonstration can handle the problem of misconceptions in students.

The aim of this study is to apply interactive demonstration learning to reduce students' misconceptions on mechanical wave material. In this study several media were used to support the success of learning using interactive demonstration, namely demonstration learning videos, PhET interactive simulation, and real laboratories.

\section{METHOD}

Interactive demonstration learning was applied in physics learning on one class students of SMA Negeri 16 Surabaya. This learning had been doing on 11-15 April 2015. This is pre experimental design of research using one group pretestposttest design. Students were given pretest to diagnose student misconceptions using a three-tier diagnostic test instrument. Furthermore, students are given mechanical wave materials using interactive demonstration learning. Students are given a posttest to determine the conception or misconception experienced by students after learning to use interactive demonstration.

The students combination answer of three-tier diagnostic test analyzed with criteria from adaptation of Kutluay [6]. Then, the combination answer clasified to UC (Understanding the Concept), LUC (Less Understanding the Concept), NUC (Do Not Understanding the Concept), M (Misconception), and $\mathrm{G}$ (Guessing). Furthermore, we have the classified answer for pretest and posttest. The data result of pretest and posttest analyzed statistically. The data of that test tested statistic using paired t-test to know the significant difference between misconception before and after learning using interactive demonstration. Data analyzed using t-test paired sample because the pretest and posttest data have met parametric statistical requirements which include normality and homogeneity test. Beside that, the data analyzed by $n-G a i n$ analyze to determine the category of reducing students misconception on mechanical wave after students learn physics using interactive demonstration. Based on data analysis can be drawn conclusion about the decrease in students misconceptions

\section{RESULTS AND DISUCUSSION}

Students learn physics using interactive demonstration with three phases, there are: (1) Predict, (2) Experience, and (3) Reflect [16]. In physics learning using interactive 
demonstration, there are several examples of cases or phenomena. This phenomenon is chosen as a learning context and demonstrated by the teacher or one group of students so that students can witness and experience firsthand the concepts being studied. In the reflecting phase in interactive demonstration learning, students are directed to reflect back on the initial concept that they have had after watching the demonstration given. This is done to find out the suitability of the students' initial concept with the concept being demonstrated. Students who experience misconceptions will realize that the concept previously owned is wrong and will change the initial concept they have into the correct scientific concept based on the demonstrations that have been carried out. Based on the results of students pre-test and post-test, we got the percentage of students conception for each item test (see Table 1).

TABLE I. THE PERCENTAGE OF STUDENTS CONCEPTION FOR EACH ITEM TEST

\begin{tabular}{|c|c|c|c|c|c|c|c|c|c|c|}
\hline \multirow{3}{*}{$\begin{array}{l}\text { Num } \\
\text { ber } \\
\text { of } \\
\text { Item } \\
\text { Test }\end{array}$} & \multicolumn{10}{|c|}{ Percentage (\%) } \\
\hline & \multicolumn{2}{|c|}{$\mathrm{UC}$} & \multicolumn{2}{|c|}{ LUC } & \multicolumn{2}{|c|}{ NUC } & \multicolumn{2}{|c|}{$\mathrm{M}$} & \multicolumn{2}{|c|}{ G } \\
\hline & Pre & $\begin{array}{c}\text { Pos } \\
\mathrm{t}\end{array}$ & Pre & $\begin{array}{c}\text { Po } \\
\text { st }\end{array}$ & Pre & $\begin{array}{c}\text { Pos } \\
\mathrm{t}\end{array}$ & Pre & $\begin{array}{c}\text { Pos } \\
\mathrm{t}\end{array}$ & Pre & $\begin{array}{c}\text { Pos } \\
\mathrm{t}\end{array}$ \\
\hline 1. & $\begin{array}{c}0.0 \\
0\end{array}$ & $\begin{array}{l}70 . \\
60\end{array}$ & $\begin{array}{l}11 . \\
80\end{array}$ & $\begin{array}{l}8 . \\
82\end{array}$ & $\begin{array}{r}44 . \\
11\end{array}$ & $\begin{array}{c}8.8 \\
2\end{array}$ & $\begin{array}{c}20 . \\
59\end{array}$ & $\begin{array}{c}5.8 \\
8\end{array}$ & $\begin{array}{c}23 . \\
50\end{array}$ & $\begin{array}{c}5.8 \\
8\end{array}$ \\
\hline 2. & $\begin{array}{l}20 . \\
60\end{array}$ & $\begin{array}{l}73 . \\
53\end{array}$ & $\begin{array}{c}2.9 \\
4\end{array}$ & $\begin{array}{l}5 . \\
88 \\
\end{array}$ & $\begin{array}{l}47 . \\
10\end{array}$ & $\begin{array}{c}2.9 \\
4\end{array}$ & $\begin{array}{l}11 . \\
76\end{array}$ & $\begin{array}{c}2.9 \\
4\end{array}$ & $\begin{array}{l}17 . \\
60\end{array}$ & $\begin{array}{l}14 . \\
71\end{array}$ \\
\hline 3. & $\begin{array}{l}47 . \\
06\end{array}$ & $\begin{array}{l}70 . \\
60\end{array}$ & $\begin{array}{c}0.0 \\
0\end{array}$ & $\begin{array}{l}2 . \\
94\end{array}$ & $\begin{array}{l}14 . \\
71\end{array}$ & $\begin{array}{c}2.9 \\
4\end{array}$ & $\begin{array}{l}32 . \\
35\end{array}$ & $\begin{array}{l}11 . \\
76\end{array}$ & $\begin{array}{c}5.8 \\
8\end{array}$ & $\begin{array}{l}11 . \\
76\end{array}$ \\
\hline 4. & $\begin{array}{l}52 . \\
95\end{array}$ & $\begin{array}{c}91 . \\
18\end{array}$ & $\begin{array}{c}2.9 \\
4\end{array}$ & $\begin{array}{l}2 . \\
94\end{array}$ & $\begin{array}{l}11 . \\
76\end{array}$ & $\begin{array}{c}0.0 \\
0\end{array}$ & $\begin{array}{l}29 . \\
41\end{array}$ & $\begin{array}{c}5.8 \\
8\end{array}$ & $\begin{array}{c}2.9 \\
4\end{array}$ & $\begin{array}{c}0.0 \\
0\end{array}$ \\
\hline 5. & $\begin{array}{l}23 . \\
53\end{array}$ & $\begin{array}{r}47 . \\
06\end{array}$ & $\begin{array}{c}2.9 \\
4\end{array}$ & $\begin{array}{l}5 . \\
88\end{array}$ & $\begin{array}{l}11 . \\
76\end{array}$ & $\begin{array}{l}17 . \\
65\end{array}$ & $\begin{array}{r}44 . \\
17\end{array}$ & $\begin{array}{l}11 . \\
76\end{array}$ & $\begin{array}{l}17 . \\
60\end{array}$ & $\begin{array}{l}17 . \\
65\end{array}$ \\
\hline 6. & $\begin{array}{l}11 . \\
76\end{array}$ & $\begin{array}{r}94 . \\
12\end{array}$ & $\begin{array}{c}0.0 \\
0\end{array}$ & $\begin{array}{c}0 . \\
00\end{array}$ & $\begin{array}{l}20 . \\
59\end{array}$ & $\begin{array}{c}2.9 \\
4\end{array}$ & $\begin{array}{l}67 . \\
65\end{array}$ & $\begin{array}{c}0.0 \\
0\end{array}$ & $\begin{array}{c}0.0 \\
0\end{array}$ & $\begin{array}{c}2.9 \\
4\end{array}$ \\
\hline 7. & $\begin{array}{c}2.9 \\
4\end{array}$ & $\begin{array}{l}50 . \\
00\end{array}$ & $\begin{array}{c}0.0 \\
0\end{array}$ & $\begin{array}{l}2 . \\
94\end{array}$ & $\begin{array}{l}23 . \\
53\end{array}$ & $\begin{array}{c}20 . \\
59\end{array}$ & $\begin{array}{l}61 . \\
76\end{array}$ & $\begin{array}{l}23 . \\
53\end{array}$ & $\begin{array}{l}11 . \\
80\end{array}$ & $\begin{array}{c}2.9 \\
4\end{array}$ \\
\hline 8. & $\begin{array}{l}17 . \\
64\end{array}$ & $\begin{array}{l}26 . \\
47\end{array}$ & $\begin{array}{c}0.0 \\
0\end{array}$ & $\begin{array}{c}0 . \\
00\end{array}$ & $\begin{array}{l}47 . \\
05\end{array}$ & $\begin{array}{l}23 . \\
53\end{array}$ & $\begin{array}{l}32 . \\
35\end{array}$ & $\begin{array}{l}41 . \\
18\end{array}$ & $\begin{array}{c}2.9 \\
4\end{array}$ & $\begin{array}{c}8.8 \\
2\end{array}$ \\
\hline 9. & $\begin{array}{c}8.8 \\
2\end{array}$ & $\begin{array}{r}41 . \\
18\end{array}$ & $\begin{array}{c}0.0 \\
0\end{array}$ & $\begin{array}{l}2 . \\
94\end{array}$ & $\begin{array}{l}35 . \\
29\end{array}$ & $\begin{array}{l}14 . \\
71\end{array}$ & $\begin{array}{l}52 . \\
94\end{array}$ & $\begin{array}{l}29 . \\
42\end{array}$ & $\begin{array}{c}2.9 \\
4\end{array}$ & $\begin{array}{l}11 . \\
76\end{array}$ \\
\hline 10. & $\begin{array}{c}8.8 \\
2\end{array}$ & $\begin{array}{l}11 . \\
76\end{array}$ & $\begin{array}{c}0.0 \\
0\end{array}$ & $\begin{array}{c}0 . \\
00\end{array}$ & $\begin{array}{l}41 . \\
18\end{array}$ & $\begin{array}{l}35 . \\
29\end{array}$ & $\begin{array}{l}50 . \\
00\end{array}$ & $\begin{array}{l}44 . \\
12\end{array}$ & $\begin{array}{c}0.0 \\
0\end{array}$ & $\begin{array}{c}8.8 \\
2\end{array}$ \\
\hline $\begin{array}{c}\text { avera } \\
\text { ge }\end{array}$ & $\begin{array}{l}19 . \\
41\end{array}$ & $\begin{array}{l}58 . \\
25\end{array}$ & $\begin{array}{c}2.0 \\
6\end{array}$ & $\begin{array}{l}2 . \\
94\end{array}$ & $\begin{array}{l}29 . \\
70\end{array}$ & $\begin{array}{l}41 . \\
18\end{array}$ & $\begin{array}{l}40 . \\
30\end{array}$ & $\begin{array}{l}17 . \\
94\end{array}$ & $\begin{array}{c}8.5 \\
3\end{array}$ & $\begin{array}{c}8.2 \\
3\end{array}$ \\
\hline
\end{tabular}

Information: Pre (pretest), Post (posttest), UC (Understanding the Concept), LUC (Less Understanding the Concept), NUC (Do Not Understanding the Concept), M (Misconception), G (Guessing)

Table 1 show the percentage of UC (Understanding the Concept), LUC (Less Understanding the Concept), NUC (Do Not Understanding the Concept), M (Misconception), and $\mathrm{G}$ (Guessing) experienced by students at pretest and posttest. Overall, the average value of UC percentage increased from $19.41 \%$ at pretest to $58.24 \%$ at posttest. The percentage increase was also shown by LUC which was from $2.06 \%$ at pretest to $2.94 \%$ at posttest. The percentage increase in the LUC category was not significant, which was only $0.88 \%$. Unlike the case with UC and LUC, the NUC, M, and G categories indicate the opposite condition. NUC, M, and G categories experience a decrease in the percentage value at posttest. The NUC category which initially had a percentage of $29.70 \%$ at pretest was $12.94 \%$ at posttest. Likewise with the $\mathrm{M}$ and $\mathrm{G}$ categories which had a decrease in the percentage values at pretest and posttest respectively $8.53 \%$ to $8.23 \%$ and $40.30 \%$ to $17.64 \%$. Decreasing the average value of percentage $M$ shows that there has been a reduction in students misconceptions. However, this decrease in misconceptions did not occur in all items.

The students answer analyzed to describe the cause of students misconception. There some cause of students misconception, there are: (1) preconception, (2) associative thinking, (3) humanistic thinking, (4) reasoning, and (5) intuition [1]. Table 2 shows the percentage value of the causes of student misconceptions for each item.

TABLE II. THE PERCENTAGE OF THE CAUSES OF STUDENTS MISCONCEPTIONS FOR EACH ITEM TEST

\begin{tabular}{|c|c|c|c|c|c|c|c|c|c|c|}
\hline \multirow{3}{*}{$\begin{array}{c}\text { Num } \\
\text { ber } \\
\text { of } \\
\text { Item } \\
\text { Test }\end{array}$} & \multicolumn{10}{|c|}{ Percentage (\%) } \\
\hline & \multicolumn{2}{|c|}{$\mathrm{P}$} & \multicolumn{2}{|c|}{ AT } & \multicolumn{2}{|c|}{ HT } & \multicolumn{2}{|c|}{$\mathrm{R}$} & \multicolumn{2}{|c|}{ I } \\
\hline & Pre & $\begin{array}{c}\text { Pos } \\
\mathrm{t}\end{array}$ & Pre & $\begin{array}{c}\text { Pos } \\
\mathrm{t}\end{array}$ & Pre & $\begin{array}{c}\text { Pos } \\
\mathrm{t}\end{array}$ & Pre & $\begin{array}{c}\text { Pos } \\
\mathrm{t}\end{array}$ & Pre & $\begin{array}{c}\text { Pos } \\
\mathrm{t}\end{array}$ \\
\hline 1. & $\begin{array}{c}0.0 \\
0\end{array}$ & $\begin{array}{c}0.0 \\
0\end{array}$ & $\begin{array}{l}14 . \\
28\end{array}$ & $\begin{array}{c}0.0 \\
0\end{array}$ & $\begin{array}{l}14 . \\
28\end{array}$ & $\begin{array}{c}0.0 \\
0\end{array}$ & $\begin{array}{c}0.0 \\
0\end{array}$ & $\begin{array}{c}0.0 \\
0\end{array}$ & $\begin{array}{l}28 . \\
60\end{array}$ & $\begin{array}{c}0.0 \\
0\end{array}$ \\
\hline 2. & $\begin{array}{c}50 . \\
00\end{array}$ & $\begin{array}{c}0.0 \\
0\end{array}$ & $\begin{array}{c}25 . \\
00\end{array}$ & $\begin{array}{c}0.0 \\
0\end{array}$ & $\begin{array}{c}25 . \\
00\end{array}$ & $\begin{array}{c}0.0 \\
0\end{array}$ & $\begin{array}{c}0.0 \\
0\end{array}$ & $\begin{array}{c}0.0 \\
0\end{array}$ & $\begin{array}{c}0.0 \\
0\end{array}$ & $\begin{array}{c}0.0 \\
0\end{array}$ \\
\hline 3. & $\begin{array}{l}18 . \\
18\end{array}$ & $\begin{array}{c}0.0 \\
0\end{array}$ & $\begin{array}{l}27 . \\
27\end{array}$ & $\begin{array}{c}40 . \\
0\end{array}$ & $\begin{array}{l}18 . \\
18\end{array}$ & $\begin{array}{c}0.0 \\
0\end{array}$ & $\begin{array}{c}0.0 \\
0\end{array}$ & $\begin{array}{c}0.0 \\
0\end{array}$ & $\begin{array}{c}0.0 \\
0\end{array}$ & $\begin{array}{r}40 . \\
00\end{array}$ \\
\hline 4. & $\begin{array}{c}20 . \\
00\end{array}$ & $\begin{array}{c}0.0 \\
0\end{array}$ & $\begin{array}{c}0.0 \\
0\end{array}$ & $\begin{array}{c}0.0 \\
0\end{array}$ & $\begin{array}{c}30 . \\
00\end{array}$ & $\begin{array}{c}100 \\
.0\end{array}$ & $\begin{array}{c}0.0 \\
0\end{array}$ & $\begin{array}{c}0.0 \\
0\end{array}$ & $\begin{array}{c}20 . \\
00\end{array}$ & $\begin{array}{c}0.0 \\
0\end{array}$ \\
\hline 5. & $\begin{array}{l}13 . \\
33\end{array}$ & $\begin{array}{c}50 . \\
00\end{array}$ & $\begin{array}{l}13 . \\
33\end{array}$ & $\begin{array}{c}0.0 \\
0\end{array}$ & $\begin{array}{c}0.0 \\
0\end{array}$ & $\begin{array}{c}0.0 \\
0\end{array}$ & $\begin{array}{l}53 . \\
30\end{array}$ & $\begin{array}{c}0.0 \\
0\end{array}$ & $\begin{array}{c}0.0 \\
0\end{array}$ & $\begin{array}{r}25 . \\
00\end{array}$ \\
\hline 6. & $\begin{array}{l}34 . \\
78\end{array}$ & $\begin{array}{c}0.0 \\
0\end{array}$ & $\begin{array}{l}34 . \\
78\end{array}$ & $\begin{array}{c}0.0 \\
0\end{array}$ & $\begin{array}{l}17 . \\
39\end{array}$ & $\begin{array}{c}0.0 \\
0\end{array}$ & $\begin{array}{c}4.3 \\
5\end{array}$ & $\begin{array}{c}100 \\
.0\end{array}$ & $\begin{array}{c}4.3 \\
5\end{array}$ & $\begin{array}{c}0.0 \\
0\end{array}$ \\
\hline 7. & $\begin{array}{l}19 . \\
05\end{array}$ & $\begin{array}{c}25 . \\
00\end{array}$ & $\begin{array}{l}47 . \\
62\end{array}$ & $\begin{array}{c}37 . \\
50\end{array}$ & $\begin{array}{l}23 . \\
81\end{array}$ & $\begin{array}{c}0.0 \\
0\end{array}$ & $\begin{array}{c}4.7 \\
1\end{array}$ & $\begin{array}{l}12 . \\
50\end{array}$ & $\begin{array}{c}0.0 \\
0\end{array}$ & $\begin{array}{r}25 . \\
00\end{array}$ \\
\hline 8. & $\begin{array}{l}45 . \\
45\end{array}$ & $\begin{array}{c}7.1 \\
4\end{array}$ & $\begin{array}{l}36 . \\
36\end{array}$ & $\begin{array}{c}0.0 \\
0\end{array}$ & $\begin{array}{l}18 . \\
18\end{array}$ & $\begin{array}{l}14 . \\
28\end{array}$ & $\begin{array}{c}0.0 \\
0\end{array}$ & $\begin{array}{l}64 . \\
28\end{array}$ & $\begin{array}{c}0.0 \\
0\end{array}$ & $\begin{array}{c}7.1 \\
4\end{array}$ \\
\hline 9. & $\begin{array}{l}16 . \\
67\end{array}$ & $\begin{array}{c}0.0 \\
0\end{array}$ & $\begin{array}{r}27 . \\
78\end{array}$ & $\begin{array}{l}18 . \\
18\end{array}$ & $\begin{array}{l}38 . \\
89\end{array}$ & $\begin{array}{l}36 . \\
36\end{array}$ & $\begin{array}{c}0.0 \\
0\end{array}$ & $\begin{array}{c}0.0 \\
0\end{array}$ & $\begin{array}{l}16 . \\
70\end{array}$ & $\begin{array}{l}27 . \\
27\end{array}$ \\
\hline 10. & $\begin{array}{l}35 . \\
29\end{array}$ & $\begin{array}{l}33 . \\
33\end{array}$ & $\begin{array}{c}0.0 \\
0\end{array}$ & $\begin{array}{l}20 . \\
00\end{array}$ & $\begin{array}{l}17 . \\
64\end{array}$ & $\begin{array}{l}26 . \\
67\end{array}$ & $\begin{array}{c}17 . \\
6\end{array}$ & $\begin{array}{c}0.0 \\
0\end{array}$ & $\begin{array}{c}23 . \\
50\end{array}$ & $\begin{array}{r}20 . \\
00\end{array}$ \\
\hline
\end{tabular}

Information: Pre (pretest), Post (posttest), P (Preconception), AT (Associative Thinking), HT (Humanistic Thinking), R (Reasoning), I (Intuition)

Based on Table 2, the percentage value of misconceptions cause decreased almost in all criteria. This is influenced by the level of misconceptions that decrease or the reduction of misconceptions. Not all causes of misconceptions experience a percentage reduction, there are still several criteria that cause misconceptions in each question that increase during posttest compared to the pretest. This can be caused by students who initially do not understand the concept or cannot answer questions correctly at level 1,2 , or 3 . After getting physics learning with interactive demonstration, students can answer questions correctly at level 1 . However at level 2, students choose reasons which is included in the criteria for the 
cause of misconceptions and students are sure of the answers so that students enter the category $M$ (misconception) and are included in the criteria for the cause of misconception in accordance with the reasons chosen by students. In addition, students who were initially unable to answer questions correctly at level 1, 2 and 3 . After getting physics learning using interactive demonstration, students still chose the wrong answer at level 1 and level 2 students also choose the reasons included in the criteria cause of misconception, but students remain confident in the answer. So that students are included in the category $\mathrm{M}$ (misconceptions) and included in the criteria for the cause of misconception in accordance with the reasons chosen by students.

Table 3 shows the data on the number of student misconceptions at the pretest and posttest. The pretest and posttest data were then statistically tested using the t-test to determine wether there were significant differences between students' misconceptions at pretest and posttest. Before analyzed by t-test, the result of normality and homogeneity test showed that data is normal and homogenous. Based on these data, the t-test is calculated. The results of t-test calculation is obtained the $t_{\text {count }}$ of 2.27 ,

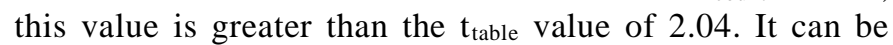
interpreted that there is a significant difference between students' misconceptions at the pretest and the posttest after students learn physics using interactive demonstration. Based on the average, it can be seen that the students' misconceptions at pretest were greater than at the posttest. This means that there is a reduction in student misconceptions on mechanical wave material after students learn using interactive demonstration. The results of this study are in accordance with Wenning's research which states that learning using interactive demonstration can reduce students' misconceptions and can improve students' conceptual understanding of a material [17].

TABLE III. THE NUMBER OF STUDENTS MISCONCEPTION AT PRETEST AND POSTTEST

\begin{tabular}{|c|c|c|}
\hline Name & $\begin{array}{c}\text { The number of } \\
\text { misconception at pretest }\end{array}$ & $\begin{array}{c}\text { The number of } \\
\text { misconception at posttest }\end{array}$ \\
\hline Student 1 & 5 & 2 \\
\hline Student 2 & 5 & 3 \\
\hline Student 3 & 6 & 3 \\
\hline Student 4 & 5 & 1 \\
\hline Student 5 & 3 & 4 \\
\hline Student 6 & 2 & 2 \\
\hline Student 7 & 3 & 1 \\
\hline Student 8 & 7 & 1 \\
\hline Student 9 & 1 & 0 \\
\hline Student 10 & 2 & 1 \\
\hline Student 11 & 7 & 3 \\
\hline Student 12 & 9 & 3 \\
\hline Student 13 & 5 & 1 \\
\hline Student 14 & 7 & 4 \\
\hline Student 15 & 2 & 2 \\
\hline Student 16 & 3 & 1 \\
\hline Student 17 & 7 & 6 \\
\hline Student 18 & 0 & 0 \\
\hline
\end{tabular}

TABLE III. CONT.

\begin{tabular}{|c|c|c|}
\hline Name & $\begin{array}{c}\text { The number of } \\
\text { misconception at pretest }\end{array}$ & $\begin{array}{c}\text { The number of } \\
\text { misconception at posttest }\end{array}$ \\
\hline Student 19 & 1 & 0 \\
\hline Student 20 & 6 & 3 \\
\hline Student 21 & 0 & 0 \\
\hline Student 22 & 6 & 0 \\
\hline Student 23 & 4 & 2 \\
\hline Student 24 & 1 & 1 \\
\hline Student 25 & 3 & 1 \\
\hline Student 26 & 0 & 0 \\
\hline Student 27 & 4 & 2 \\
\hline Student 28 & 3 & 2 \\
\hline Student 29 & 6 & 2 \\
\hline Student 30 & 6 & 3 \\
\hline Student 31 & 7 & 4 \\
\hline Student 32 & 3 & 2 \\
\hline Student 33 & 5 & 2 \\
\hline Student 34 & 0 & 0 \\
\hline
\end{tabular}

To determine the category of reducing students misconception on mechanical wave after students learn physics using interactive demonstration, the data analyzed by $\mathrm{n}$-Gain analysis. Table 4 show the result of $\mathrm{n}$-Gain analysis for reduction of students misconception on mechanical wave physics learning. Based on this table, 6 students included in the high criteria, 19 students included in the medium criteria, and 9 students included in the low criteria.

TABLE IV. THE STUDENT REDUCING MISCONCEPTION CRITERIA BASED ON N-GAIN ANALYSIS

\begin{tabular}{|l|c|c|c|c|}
\multicolumn{7}{c}{ CRITERIA BASED ON N-GAIN ANALYSIS } \\
\hline Name & $\mathrm{Si}$ & $\mathrm{Sf}$ & $<\mathrm{g}>$ & Criteria \\
\hline Student 5 & 50.00 & 40.00 & 0.20 & Low \\
\hline Student 6 & 20.00 & 20.00 & 0.00 & Low \\
\hline Student 15 & 20.00 & 20.00 & 0.00 & Low \\
\hline Student 17 & 70.00 & 60.00 & 0.14 & Low \\
\hline Student 18 & 0.00 & 0.00 & 0.00 & Low \\
\hline Student 21 & 0.00 & 0.00 & 0.00 & Low \\
\hline Student 24 & 10.00 & 10.00 & 0.00 & Low \\
\hline Student 26 & 0.00 & 0.00 & 0.00 & Low \\
\hline Student 34 & 0.00 & 0.00 & 0.00 & Low \\
\hline Student 1 & 50.00 & 20.00 & 0.60 & Medium \\
\hline Student 2 & 50.00 & 30.00 & 0.40 & Medium \\
\hline Student 3 & 60.00 & 30.00 & 0.50 & Medium \\
\hline Student 7 & 30.00 & 10.00 & 0.67 & Medium \\
\hline Student 10 & 20.00 & 10.00 & 0.50 & Medium \\
\hline Student 11 & 70.00 & 30.00 & 0.57 & Medium \\
\hline Student 12 & 90.00 & 30.00 & 0.67 & Medium \\
\hline Student 14 & 70.00 & 40.00 & 0.42 & Medium \\
\hline Student 16 & 30.00 & 10.00 & 0.67 & Medium \\
\hline Student 20 & 60.00 & 30.00 & 0.50 & Medium \\
\hline Student 23 & 40.00 & 20.00 & 0.50 & Medium \\
\hline Student 25 & 30.00 & 10.00 & 0.67 & Medium \\
\hline Student 27 & 40.00 & 20.00 & 0.50 & Medium \\
\hline Student 28 & 30.00 & 20.00 & 0.33 & Medium \\
\hline Student 29 & 60.00 & 20.00 & 0.67 & Medium \\
\hline Student 30 & 60.00 & 30.00 & 0.50 & Medium \\
\hline Student 31 & 70.00 & 40.00 & 0.43 & Medium \\
\hline Student 32 & 30.00 & 20.00 & 0.33 & Medium \\
\hline Student 33 & 50.00 & 20.00 & 0.60 & Medium \\
\hline Student 4 & 50.00 & 0.00 & 1.00 & High \\
\hline Student 8 & 70.00 & 10.00 & 0.85 & High \\
\hline Student 9 & 10.00 & 0.00 & 1.00 & High \\
\hline Student 13 & 50.00 & 10.00 & 0.8 & High \\
\hline Student 19 & 10.00 & 0.00 & 1.00 & High \\
\hline Student 22 & 60.00 & 0.00 & 1.00 & High \\
\hline
\end{tabular}


The number of students in each category of reduction of misconception, it can be stated that the percentage of students who experienced a reduction in misconception in the low criteria was $26.47 \%$. while for the reduction category misconception in the medium criteria is $55.90 \%$, and in the high criteria is $17.64 \%$. Based on this percentage, it can be stated that physics learning using interactive demonstration has a moderate influence on the reduction of students' misconceptions on mechanical wave material

\section{CONCLUSION}

The conclusion of this study is students' misconceptions on mechanical wave material can reduce using interactive demonstration learning, eventhough one item test show the enhancement of students' misconception. It is advisable to further researchers when selecting demonstration media in interactive demonstration learning to conduct live demonstrations, not only with video or simulation.

\section{ACKNOWLEDGMENT}

The authors would like to thanks for the physics teachers and students of $16^{\text {th }}$ State Senior High School of Surabaya so we can study this topic.

\section{REFERENCES}

[1] P. Suparno, Miskonsepsi dan Perubahan Konsep dalam Pendidikan Fisika, Jakarta: PT Grasindo, 2013.

[2] X. Vamvakoussi and S. Vosniadou, "How Many Decimals Are There Between Two Fractions? Aspects of Secondary School Students' Understanding of Rational Numbers and Their Notation", Cognition Instr., vol. 28, no. 181, pp. 181-209, 2010.
[3] M. Hidayatulloh, F. Humairoh, U. Wachidah, D. A Iswati, and Suliyanah, "Pengembangan Perangkat Pembelajaran Untuk Mereduksi Miskonsepsi Siswa Pada Materi Rangkaian Listrik Dengan Scientific Approach", J. Penelit. Fis. Apl. Vol. 5, no. 1, p. 28, 2015.

[4] M. Habibbulloh, B. Jatmiko, and W. Widodo, J. Penelit. Fis. Apl., vol. 7, no. 1, p. 27, 2017.

[5] Suliyanah, H. N. P. A. Putri, L. Rohmawati, "Identification student's misconception of heat and temperature using three-tier diagnostic test", J. Phys. Conf. Ser., vol. 997, no. 1, 2018.

[6] M. N. R. Jauhariyah, I. Zulfa, Z. Harizah, and W. Setyarsih, "Validity of student's misconceptions diagnosis on chapter Kinetic Theory of Gases using three-tier diagnostic test “, J. Phys.: Conf. Ser., vol. 997, no. $1,2018$.

[7] M. N. R. Jauhariyah, N. Suprapto, Suliyanah, S. Admoko, W. Setyarsih, Z. Harizah, and I. Zulfa, "The Students' misconceptions profile on chapter gas kinetic theory", J. Phys. Conf. Ser., vol. 997, no. $1,2018$.

[8] A. C. Prastiwi, A. Kholiq, and W. Setyarsih, "Implementation of ECIRR model based on virtual simulation media to reduce students' misconception on kinetic theory of gases", J. Phys. Conf. Ser., vol. 997, no. $1,2018$.

[9] T. Hidayati, S. E. Nugroho, and Sudarmin, Unnes Science Education Journal, vol. 2, no. 2, p. 311, 2013.

[10] R. Elfani, Profil Miskonsepsi Siswa Kelas XI pada Materi Gelombang Bunyi berdasarkan hasil three-tier test, Bandung: Universitas Pendidikan Indonesia, 2013.

[11] E. V. D. Berg, Miskonsepsi Fisika dan Remediasi, Salatiga: Universitas Kristen Satya Wacana, 1991

[12] R. W. West and R. T. Odgen, "Interactive Demonstrations for Statistics Education on the World Wide Web", Journal of Statistics Education vol. 6, no. 3, 1998.

[13] A. Mazzolini, Daniel, and Edwards, "Using Interactive Lecture Demonstrations to Improve Conceptual Understanding of Resonance in an Electronics Course", Australian Journal of Engineering Education, vol. 18 , no. $1,2012$.

[14] Wijaya I K W B, Kirna, and Suardana, "Model Demonstrasi Interaktif Berbantuan Multimedia dan Hasil Belajar IPA Aspek Kimia Siswa SMP”, Jurnal Pendidikan dan Pengajaran, vol. 45, no. 1, p. 88, 2012.

[15] F. N. Annisa, Karim, and Aminudin, Jurnal Pengajaran MIPA, vol. 19, no. 1, p. $88,2014$.

[16] R. Hake, Interactive-engagement Methods in Introductory Mechanic Courses, Bloomington: Indiana University, 1998.

[17] C. J. Wenning, "Helpful Themes in Physics Teachers Preparation and Professional Development", J. Phys. Tchr. Educ., vol. 6, no. 2, 2013. 